Prepared in cooperation with the city of Olathe, Kansas

\title{
Monitoring the Water Quality of Lake Olathe, Johnson County, Kansas
}

\author{
By Patrick P. Rasmussen ${ }^{1}$ and DeWayne H. McAllister ${ }^{2}$
}

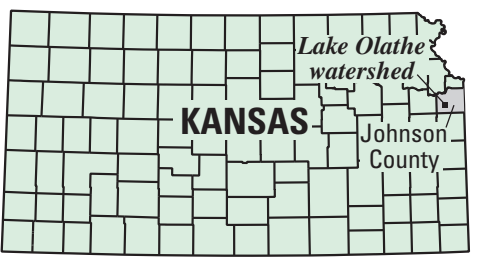

\section{Why Monitor Water Quality?}

Lake Olathe was built in 1956 and provides recreation and supplements the drinking water for an estimated 105,000 residents of Olathe, Kansas (U.S. Census Bureau, 2003). The water quality of the lake is affected by land use and activities occurring in the Lake Olathe watershed. Since construction of the reservoir, drinking water from Lake Olathe has experienced seasonal tasteand-odor problems caused by algae blooms (Lee and Sears, 1985; Mau, 2004) and elevated manganese concentrations. Although the water can be treated to remove taste and odor, the process is expensive, and objectionable taste and odor is not always easy to detect because individuals have different sensitivities. During the summer months, higher manganese concentrations in the deeper parts of the lake also can cause drinking-water-quality issues.

An ongoing study of Lake Olathe water quality began in 2000 as a cooperative agreement between the city of Olathe and the U.S. Geological Survey (USGS). As part of the study, sediment and chemical transport from the watershed to the reservoir were defined, and the monitoring of sediment and chemical transport continues. Information from this study assisted city of Olathe officials in developing a comprehensive watershed protection plan (Lake Olathe Watershed Protection Citizen Advisory Board, 2004) and currently (2005) is used to inform the drinking-watertreatment managers of Lake Olathe water quality.

As part of the study, chemical and biological processes that cause taste and odor also are being investigated with the aid of a water-quality monitor in Lake Olathe and water samples collected from Cedar Creek (the main tributary to Lake Olathe) and Lake Olathe. A profiling water-quality monitor was installed in 2005 to monitor ever-changing water-quality conditions at various depths in the lake. Measurements at the 5.0-foot depth are displayed on the World Wide Web (http:// waterdata.usgs.gov/ $\mathrm{ks} / \mathrm{nwis} / \mathrm{uv} /$ ?site_no $=06892450$ ) in real time so that water-treatment managers can determine the most desirable water-withdrawal strategies to best meet Olathe's drinking-water needs.

\section{What Causes Taste and Odor?}

The historical taste-and-odor occurrences observed in water from Lake Olathe are caused primarily by a specific group of algae called blue-green algae. A healthy lake has a balanced algal community that causes little or no taste and odor. This balance can be disrupted by any number or combination of the following conditions:

- Excessive nutrient concentrations (such as nitrogen and phosphorus) in the lake promote algal growth.

- Sunlight and water temperatures can favor certain algal species more than others.

- Pesticides applied within the watershed and transported to the lake in runoff can affect certain algal species.
A disruption of the algal community balance that results in blue-green algae becoming the dominant species will frequently have a negative effect on the taste and odor of lake water. Compounds released from blue-green algal blooms and the death and decay of blue-green algae can result in taste and odor in the water. Therefore, maintaining good water quality in the lake reduces the possibility of blue-green algal blooms. A blue-green algae sensor was installed in 2005 to provide drinking-water managers with data to monitor the probability of a taste-and-odor occurrence.

\section{What's Been Done So Far?}

To gain a historical perspective of the watershed water quality, sampling of lake-bottom sediment at Lake Olathe and Cedar Lake was done in 2000. Chemical concentrations and diatoms in the sediment indicate historical water-quality conditions. Results from this part of the study (Mau, 2002) were:

- Cedar Lake is effective at trapping sediment that would have been deposited in Lake Olathe.

- Fifty percent of the original storage capacity of Cedar Lake is filled with sediment.

- Ten percent of the original storage capacity of Lake Olathe is filled with sediment.

- Phosphorus concentrations in the bottom sediment of Cedar Lake and Lake Olathe are some of the largest values for small reservoirs surveyed in eastern Kansas (Juracek, 2004).

- Diatoms (microscopic algae) observed in the bottom sediment indicate conditions that were favorable to taste-andodor occurrences throughout much of Lake Olathe's life.

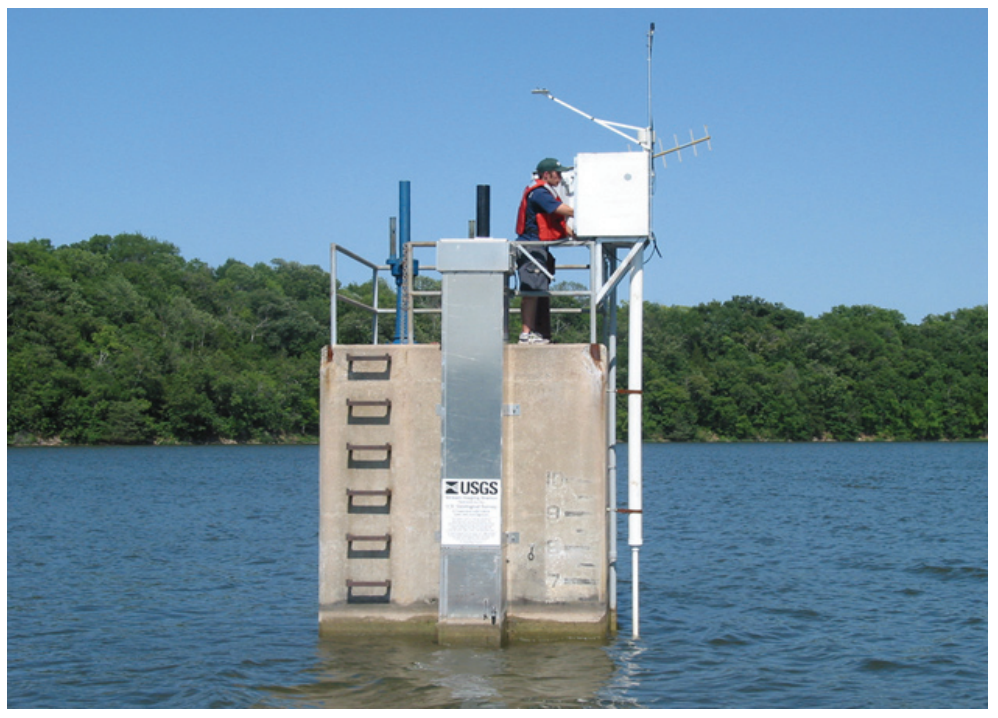

Photograph showing USGS technician working on the intake structure at Lake Olathe.

\footnotetext{
1 U.S. Geological Survey, Lawrence, Kansas.

2 City of Olathe, Olathe, Kansas.
} 
A report describing surface-water-quality conditions in the Lake Olathe watershed during 2000-02 was based on waterquality samples and continuous measurement of water-quality characteristics (Mau, 2004). Results from this part of the study were:

- Nitrogen and phosphorus are transported from the watershed to Cedar Creek and Lake Olathe.

- Phosphorus is released from the bottom sediment into the lake water providing more nutrients to the algal community and possibly increasing the likelihood of taste-andodor occurrences.

- Models were developed to estimate the nutrient and tasteand-odor compounds at Lake Olathe and Cedar Creek in real time (http://ks.water.usgs.gov/Kansas/rtqw) to help water-treatment managers adjust water treatment. Algal blooms are best explained by lake-residence time, turbidity, light penetration, and nutrient concentrations.

- Algal toxins and taste-and-odor compounds were detected at various concentrations in Lake Olathe, but none of the concentrations were large enough to adversely affect taste and odor of finished drinking water.

Currently (2005), USGS is monitoring lake water quality by periodically collecting samples from Cedar Creek and Lake Olathe and by continuously monitoring various water-quality characteristics, including dissolved oxygen (fig. 1), at both intake elevations in the lake. Dissolved-oxygen concentrations less than 1.0 milligram per liter indicate the increased possibility of elevated manganese concentrations. Water-quality profile measurements are available on the World Wide Web (http:// ks.water.usgs.gov/Kansas/rtqw/) for water-treatment managers to evaluate and determine which intake to use and how to optimize water treatment.

Further monitoring of the lake water quality will provide the city with information to evaluate the effectiveness of recommendations from the Lake Olathe Watershed Protection Citizen Advisory Board's report (2004). Long-term monitoring of Lake Olathe will help assess watershed activities that affect the water quality of this important source of drinking water and recreation for Olathe residents.

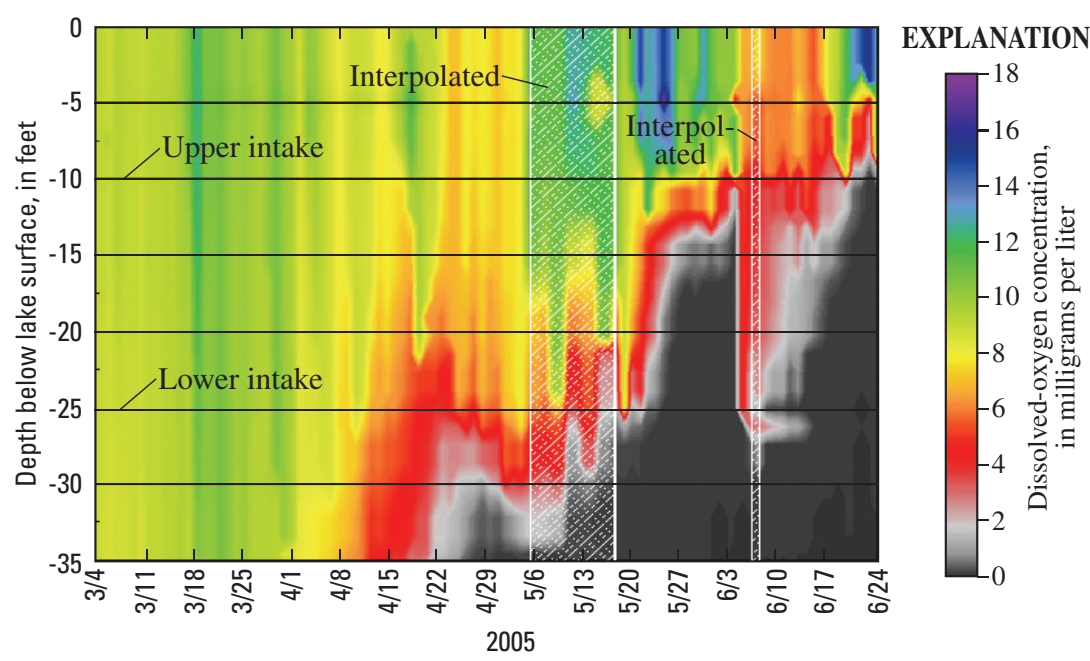

\section{Where Does Olathe's Drinking Water Come From?}

Drinking water for Olathe residents comes from aquifers recharged by the Kansas River, with Lake Olathe supplementing water supply during high-use, summer months. Ninety percent of Olathe's drinking water is pumped from wells in the Kansas River alluvium and treated and distributed at Water Treatment Plant 2. Typically, from July to September, Water Treatment Plant 1 treats and distributes water from Lake Olathe, supplementing increased needs sustained during summer months. Since 2000 , lake levels have been drawn down as much as 8.5 feet during the summer months. However, intakes at two different elevations on the intake structure allow water to be pumped from the lake when lake levels decline (fig. 2).

The intake structure also can be operated on the basis of water-quality conditions. In June 2004, elevated manganese concentrations in the deeper part of the lake prompted the city to close the lower intake and open the upper intake. Although not the case in 2004, taste and odor caused by algae blooms has been an issue for water pumped from the upper intake.

\section{References Cited}

Juracek, K.E., 2004, Sedimentation and occurrence and trends of selected chemical constituents in bottom sediment of 10 small reservoirs, eastern Kansas: U.S. Geological Survey Scientific Investigations Report 2004-5228, 80 p.

Lake Olathe Watershed Protection Citizen Advisory Board, 2004, Lake Olathe watershed restoration and protection plan: Olathe, Kansas, City Council study session, $77 \mathrm{p}$.

Lee, G.F., and Sears, R.I., 1985, Kansas Clean Lakes Program, Lake Olathe: prepared for city of Olathe, Kansas, various pagination.

Mau, D.P., 2002, Sediment deposition selected water-quality characteristics in Cedar Lake and Lake Olathe, northeast Kansas, 2000: U.S. Geological Survey Water-Resources Investigations Report 02-4073, $71 \mathrm{p}$.

Mau, D.P., 2004, Surface-water-quality conditions and relation to taste-and-odor occurrences in the Lake Olathe watershed, northeast Kansas, 2000-02: U.S. Geological Survey Scientific Investigations Report 2004-5047, 95 p.

U.S. Census Bureau, 2003, Estimated 2003 population for Olathe, Kansas: Population Division, information available on Web, accessed May 5, 2005, at http://www. census.gov/popest/cities/tables/SUB-EST2003-04-20.xls

For additional information on the water-quality study of the Lake Olathe watershed, visit the USGS Web site

at

http://ks.water.usgs.gov/Kansas/qw/olathe/

or contact

the Director of the USGS Kansas Water Scence Center 4821

Quail Crest Place, Lawrence, Kansas 66049-3839 (785) 842-9909 or E-mail: dc_ks@usgs.gov

Figure 1. Dissolved-oxygen concentrations in water at intake structure, Lake Olathe, March 4-June 24, 2005. 